\title{
GREEK COASTAL MIRES: A PRELIMINARY STUDY OF THE AGOULINITSA PEATLAND, WESTERN PELOPONNESE
}

\author{
Sofikitis E. ${ }^{1}$, Siavalas G. ${ }^{1}$, Chatziapostolou A. ${ }^{1}$, Kalaitzidis S. ${ }^{1}$, and \\ Christanis K. ${ }^{1}$
}

${ }^{1}$ Section of Earth Materials, Department of Geology, University of Patras, GR-265.00 RioPatras,Greece,sailis@otenet.gr,siavalas@upatras.gr,achatzia@upatras.gr, s.kalaitzidis@upatras.gr,christan@upatras.gr

\begin{abstract}
The Agoulinitsa peatland formed on the western shore of the homonymous lake, which was drained in 1969 because of the emerging demand for agricultural land. This study is a preliminary attempt to determine the conditions that prevailed during peat formation. Shallow cores were obtained from the peatland and initial physical, chemical and mineralogical analyses were carried out. High ash yield and $\mathrm{pH}$ values indicate that peat accumulated under alkaline conditions with periods of high clastic material influx, while high electric conductivity values indicate increased influx of dissolved solids into the mire. The mineral matter consists mainly of clay minerals, quartz, calcite, halite, sylvite and pyrite. The distribution of these minerals with depth indicates that fresh-water conditions prevailed for a long period during peat accumulation at the central part of the peatland, whereas the sea-water influence was more intense to the south establishing slightly brackish conditions. All data suggest that the Agoulinitsa peatland was developed as a back-barrier mire formed at the southwestern part of the Agoulinitsa Lake, and hence it can be considered as a modern analogue of the Neogene lignite deposits occurring along the west coast of Peloponnese.
\end{abstract}

Key words: back-barrier mire, peat, wetland, drainage.

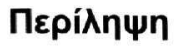

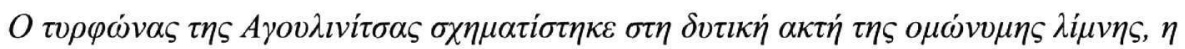

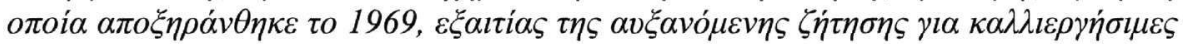

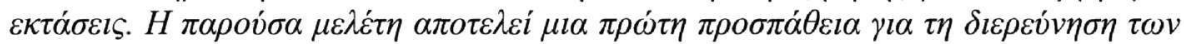

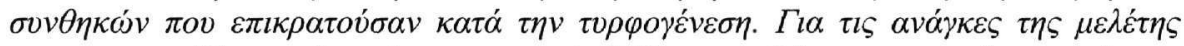

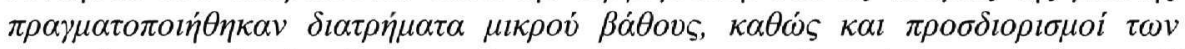

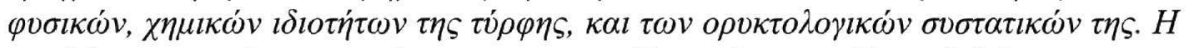

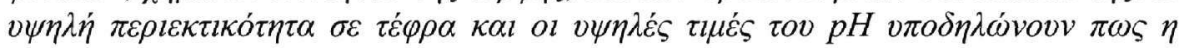

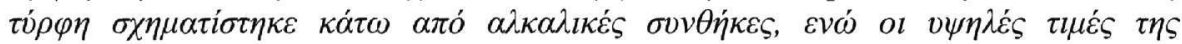

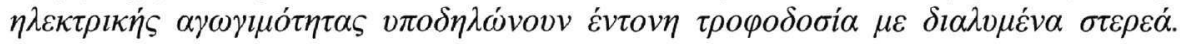

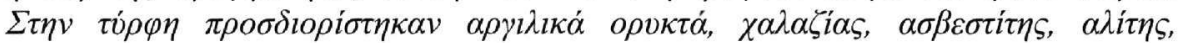

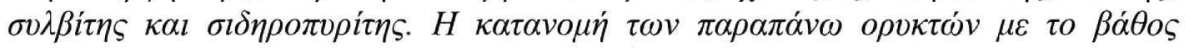

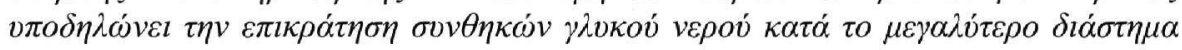

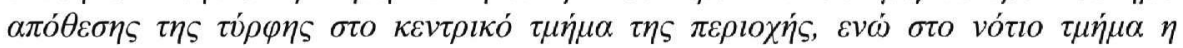




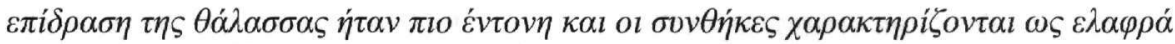

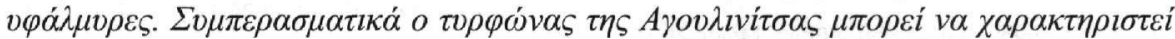

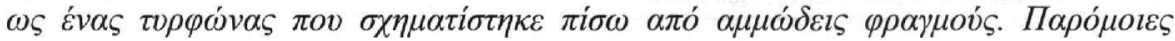

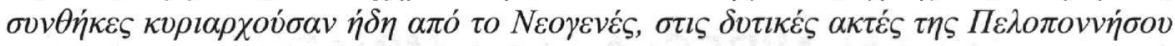

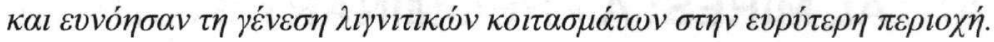

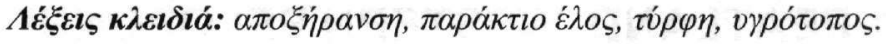

\section{Introduction}

In the past decades the wetlands - among them the mires - have attracted the interest of the scientific community as places of high environmental significance, because of the diversity of flora and fauna species living there, as well as due to the fact that they constitute major freshwater deposits. Mires are wetlands of great environmental and economic value, hence in order to preserve these ecosystems it is necessary to study the natural processes that affect mire evolution. Furthermore the study of modern peat-forming environments constitutes the key for better understanding of the various coal-forming processes (Diessel 1992, Lappalainen 1996, Joosten and Clark 2001).

From ancient times up to late 1960's, several mires in Greece, as well as shallow lakes have been drained mainly due to the demand for fertile agricultural land (Psilovikos 1992, Bouzinos et al. 1994). Nevertheless, across the territory mires are still developing usually under minerotrophic to weakly minerotrophic conditions. Peat is accumulating mainly under slightly acidic $\mathrm{pH}$ values ranging between 4 and 6 (e.g. Christanis 1994, Papazisimou et al. 2000, 2002). Minerotrophic mires (fens) are distinguished in those formed in intermontane basins such as the fens of Philippi, Nissi, Chimaditida, Ioannina, Kalodiki, Katouna and Small Prespa (Christanis 1996, Bouzinos et al. 2001) and coastal fens like this in Keri, which is the only active one recorded up to now in the country (Papazisimou et al. 2000).

The area of the Agoulinitsa Lake with the homonymous mire covers about $46.3 \mathrm{~km}^{2}$ and is located in western Peloponnese, approximately $7.5 \mathrm{~km}$ SSE from the town of Pyrgos (Fig. 1a). After an extended drainage project in 1969 the lake area was converted into urban and agricultural land (Manariotis and Yannopoulos 2004).

The aims of the present preliminary study are to inventorize the main characteristics of the Agoulinitsa peatland and to identify the conditions that prevailed before and during peat accumulation, as well as after the drainage.

\section{Geological setting}

The Agoulinitsa Lake once covered the central-western part of the Pyrgos Basin, which formed during the post-alpidic extensional phase. The Agoulinitsa sub-basin evolution is controlled by the Pyrgos Fault striking NNW-SSE (Fig. 1a) (Koukouvelas et al. 1996). The SE margins of the former lake area consist of limestones of the Gavrovo-Tripoli isopic zone. Pliocene alternations of clay, lignite, sand, silt, sandstone and conglomerate and Pleistocene alternations of clay, sand, conglomerate and breccia of the Pyrgos Basin constitute the eastern margins, while the western margins consist of Quaternary sand dunes (Fig. 1b). The sediments filling the Agoulinitsa Lake, as well as its northern margins are alluvial deposits (sand, gravel and pebble) of the Alpheios River and lagoonal sediments (Kamberis 1987).

The study area has a typical temperate Mediterranean climate, with cold-wet winters and warmdry summers. According to the data of the Hellenic National Meteorological Service during the last 30 years, the mean annual precipitation is $700 \mathrm{~mm}$ unevenly distributed through out the year. Before the drainage the coastal zone of the Agoulinitsa Lake was covered by sand-dune and halophytic vegetation, while helophytes were dominant at the largest part of the lake. The main helophytic species were Scirpus spp., Phragmites australis, and various Cyperaceae (Natura 2000, 


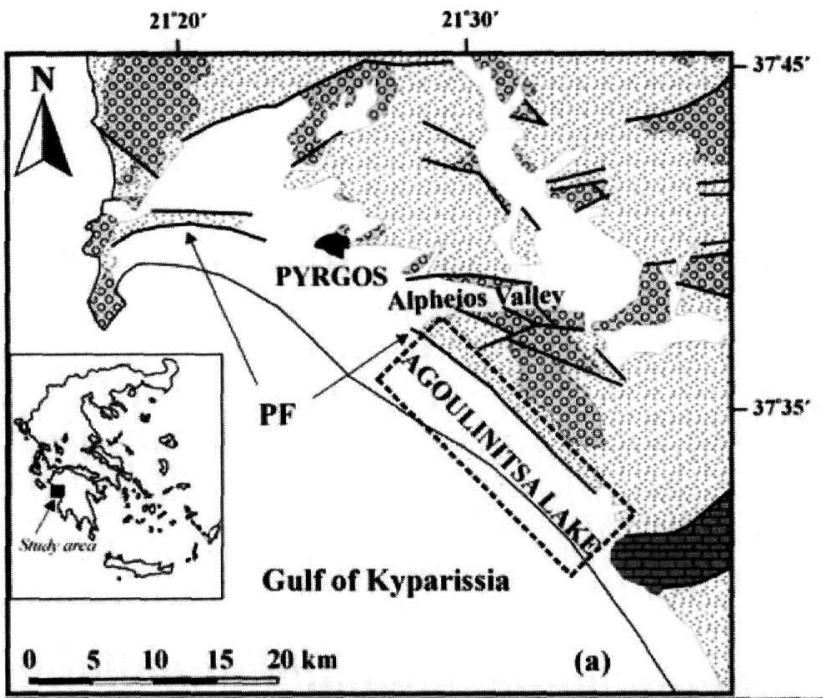

\section{LEGEND}

Alluvial deposits

(Pebble, gravel and sand)

PLEISTOCENE

\%영 Alternations of clay, sand, conglomerate and breccia

PLIOCENE

Alternations of clay, lignite, silt, sand sandstone and conglomerate

MESOZOIC

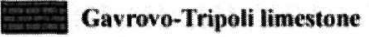

Normal fault

PF Pyrgos Fault

(b)
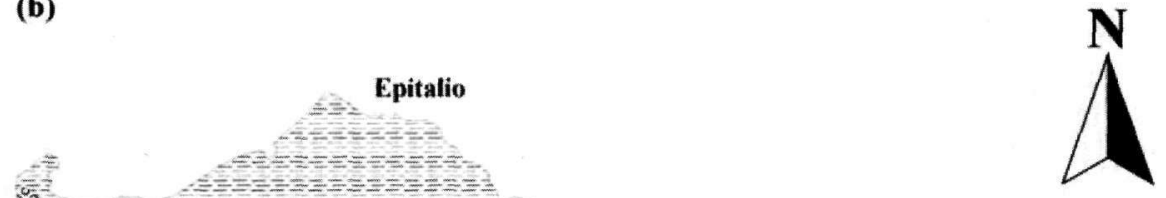

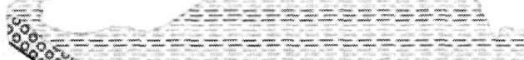

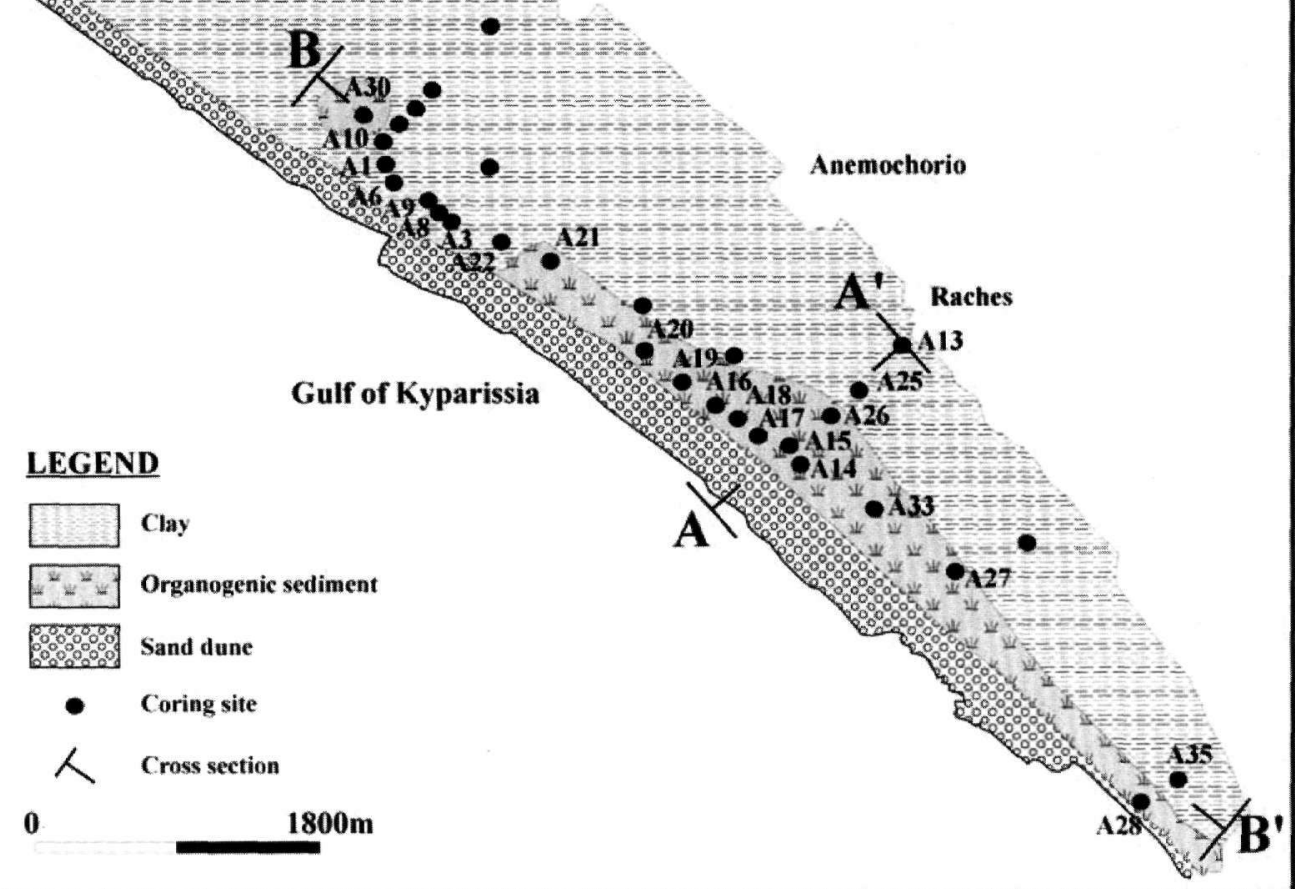

Figure 1 - a) Simplified geological map of the Pyrgos Basin (after Kamberis 1987 and Papazisimou et al. 2004). b) Geological map of the study area. Cross sections AA' and BB' are presented in Figure 3 
http://natura.minenv.gr). Today the land is mainly used for cotton cultivation and pasture; both activities result in the regression of the helophytic vegetation, except from the SE part of the drained Agoulinitsa Lake.

\section{Materials and Methods}

Using an Edelman hand-driven corer, thirty-five cores (Fig. 1b) were obtained up to a maximum depth of $3.65 \mathrm{~m}$. The cores were logged at the site and the degree of peat decomposition was determined according to the von Post method (Schneekloth 1981). Samples were picked up from cores $\mathrm{A}_{33}$ and $\mathrm{A}_{35}$.

Moisture and ash contents of all the samples were determined according to the ASTM D3173 (1993) and D2974 (Andrejko et al. 1983) methods, respectively. The $\mathrm{pH}$ and the electric conductivity values were measured in aqueous solution (1:25 sample/water ratio).

The mineralogical analyses of the bulk peat samples obtained from coring sites $\mathrm{A}_{33}$ and $\mathrm{A}_{35}$, were carried out using a Philips PW1050 X-Ray diffractometer. The scanning area covered the interval $2 \theta 3-60^{\circ}$, with a scanning step of $0.02^{\circ}$ and a step time of $1 \mathrm{~s}$. The semi-quantitive evaluation was performed according to the method proposed by Papazisimou and Kalaitzidis (2004).

\section{Results and discussion}

\subsection{Lithological data}

The stratigraphic features of the peatland were plotted according to the lithological data and the laboratory sample characterization (Fig. 2). It was revealed that the palaeomire developed over a ca. $6 \mathrm{~km}$ long, narrow zone along the eastern margin of the sand dune barrier. The maximum width of the palaeomire was c. $800 \mathrm{~m}$ (Fig. 1b).

The maximum peat thickness reaches $335 \mathrm{~cm}$ at coring site $\mathrm{A}_{28}$. Macroscopically the peat has a light brown to black color. Rhizomes, plant macro-remains and molluses frequently occur within the peat. The humification degree according to the von Post method ranges from 7 to 8 , indicating significant humification of the organic matter. Nowadays the helophytes growing on the surface are mainly Scirpus spp. and other Cyperaceae species, along with Juncus spp. and Phragmites australis.

Apart from peat, other organogenic limnotelmatic facies, like detrital and clayey mud occur at several sites. The surface peat layer is strongly degraded and oxidized because of the drainage. According to local farmers, since the initiation of the cultivation after the drainage, the surface level has subsided approximately $1.5 \mathrm{~m}$, because of the oxidation and the subsequent loss of the uppermost peat layers. Hence it is inferred that before 1969 the peat thickness exceeded $4.5 \mathrm{~m}$. The loss of organic matter because of oxidation and self-ignition of the surface peat layer is common to intensely cultivated peatlands; as an example in Chimaditida fen, the subsidence of the surface peat layer resulted in a loss of the initial thickness between $47.4 \%$ and $77.3 \%$ (Bouzinos et al. 1997). Lowering peat surface after drainage also occurs in Philippi peatland, where the upper peat layer subsided $3.5 \mathrm{~m}$ within a period of fifteen years only because of the intense cultivation (van der Molen 1962).

Clay and sand layers constitute the inorganic sediments in the area of the palaeomire. The sand layer probably constitutes the substrate of the limnotelmatic environment representing the dune system that developed across the coastline, whereas the clay layers represent the limnic facies that deposited during flooding events; intermediate facies (e.g. clayey sand, sandy clay) occur throughout the sequence. 

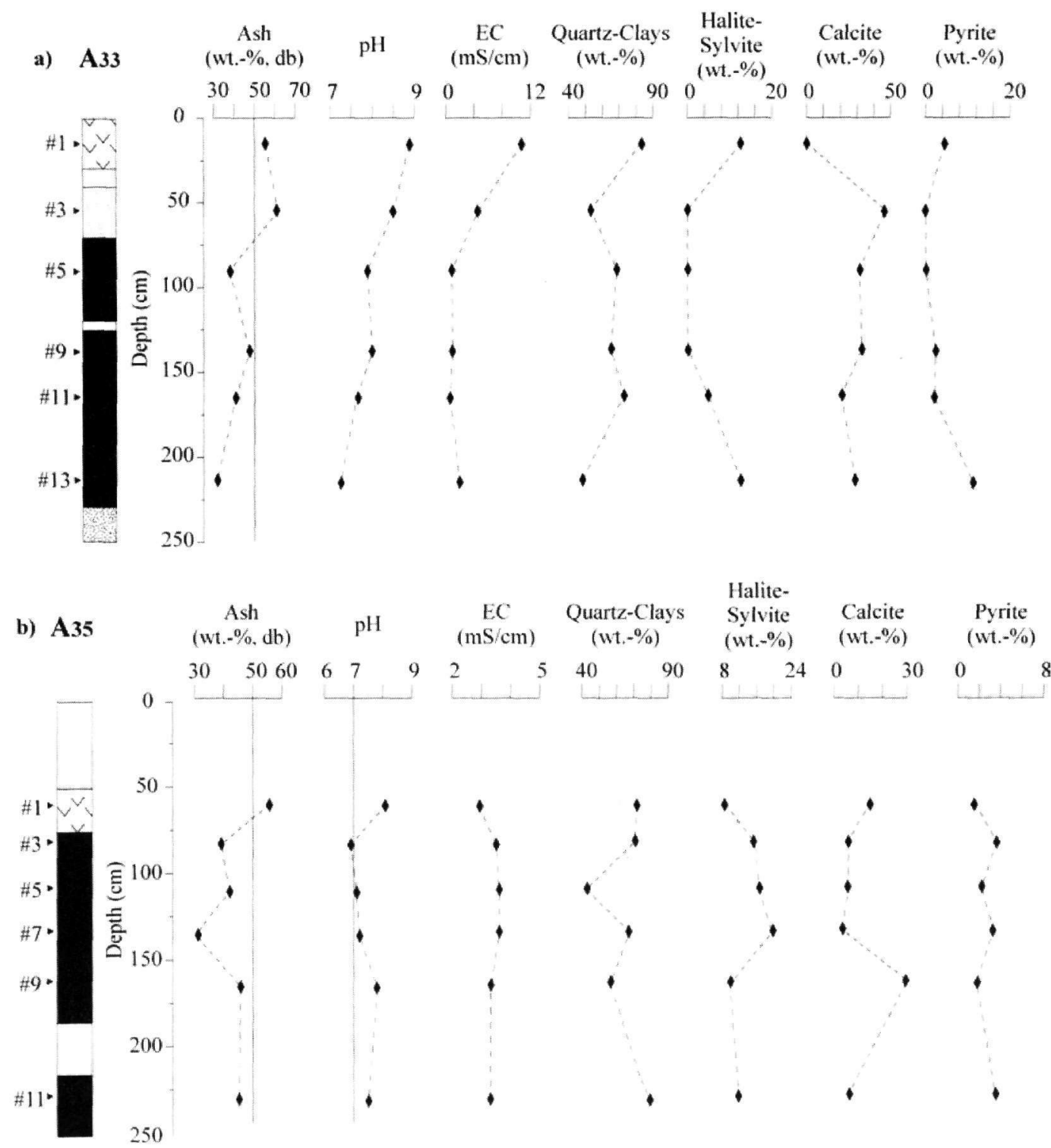

\section{LEGEND}

Peat

Clay $v$ Peaty mud

Clayey mud

Sandy clay

Figure 2 - Ash yield, pH, EC (electric conductivity), and mineral content distribution along the $A_{33}$ and $A_{35}$ cores (db: on dry basis). Organogenic samples with ash content $<50 \%$ are regarded as peat, $50-60 \%$ as peaty mud, $60-80 \%$ as mud and $80-90 \%$ as humic clay, silt or sand, depending on the grain size of the sediment (Kearns and Davison 1983)

\subsection{Laboratory determinations and peat characterization}

Moisture and ash content of the examined organogenic samples range from 67.9 to $86.6 \%$ and 31.5 to $61.6 \%$, respectively (Fig. 2). The relatively high ash content indicates high inorganic material input during the whole time span of peat accumulation. 
The $\mathrm{pH}$ values ranging from 6.9 to 8.7 , reveal a neutral to alkaline environment at both sites. The relatively high $\mathrm{pH}$ values of the Agoulinitsa peat indicate probably seawater influence and/or significant carbonate influx. The establishment of neutral to alkaline conditions apart from neutralizing the organic acids (Shotyk 1988), promotes the biological activity and accordingly the humification of the plant remnants (Moore and Bellamy 1976, Göttlich 1990); this process is reflected in the high humification degree of the studied samples. The electric conductivity values are relatively high $(0.6-10.7 \mathrm{mS} / \mathrm{cm})$ revealing high content of dissolved solids (salt), also as an evident of marine influence (Göttlich 1990).

The semi-quantitative determinations of the mineral matter in the bulk peat samples show that quartz, mixed-layer clays (illite-montmorillonite) and calcite constitute the main mineral phases in the Agoulinitsa peat, whereas pyrite, halite and sylvite constitute the minor phases (Fig. 2). In general, both quartz and clays in peat and coal are considered as having a clastic origin, whereas calcite occurs either as clastic grain or as authigenic mineral (Diessel 1992, Ward 2002). Pyrite in coastal mires usually derives from the reduction of the seawater sulphates and the reaction of the $\mathrm{H}_{2} \mathrm{~S}$ with $\mathrm{Fe}$-ions, which derive from detrital material entering the mire during flood episodes (Delwigg et al. 2001). Halite and sylvite usually indicate the sea influence and may be deposited either from seawater solutions or by the wind action (Raymond et al. 1983). The mineralogical composition of the Agoulinitsa peat is identical to that of the Keri with the presence of quartz, clay minerals, calcite and pyrite. The existence of halite and sylvite is characteristic for coastal peatlands, while these two minerals are lacking from Greek fen peats deposited in intermontane basins (Kalaitzidis and Christanis 2004).

An interesting feature is the presence of analcime and plagioclase (21.7 and $11.4 \mathrm{wt.} \%$, respectively) in sample \#5 from core $\mathrm{A}_{35}$ Analcime in peat is usually related to volcanic ash (Querol et al. 2001). Volcanic tuff layers, however, were not identified macroscopically and further investigation on this subject is needed.

\subsection{Peat formation in the Agoulinitsa peatland}

The activation of the Pyrgos Fault during the Lower Pleistocene caused the subsidence of the western coastal area of Peloponnese (Koukouvelas et al. 1996), where the interaction of wind and waves resulted in the formation of sand barriers. Behind them the conditions were favourable for the formation of several lagoons, one of them occurring in the Agoulinitsa area.

According to the stratigraphic features and the laboratory determinations it is evident that the palaeomire was established behind the sand dune zone at low water-table conditions (Fig. 3a). The sand dune barriers acted as obstacles preventing sea intrusion during the lagoon's terrestrialization. Short-term flooding events resulted in the rise of the water table and the establishment of lacustrine conditions, which led to the formation of clay lenses intercalating with peat (Fig. 3b). At later evolutionary stages it seems that peat accumulation was restricted to the central and SE part, while lacustrine conditions were dominant in the NW part.

The high halite, sylvite and pyrite contents at the lower peat layer from core $A_{33}$, along with the high electric conductivity values (Fig. 2a), indicate that seawater influence was intense at the early stages of peat accumulation in the central part of the palaeomire. Gradually upwards the freshwater contribution to peat formation became more significant. Short-term flooding events caused the transport of clastic material and the interruption of peat formation by the deposition of clay layers. The flooding events were obviously caused by the activity of the Alpheios River.

The uppermost peat horizon at site $\mathrm{A}_{33}$ is oxidized due to the drainage of the former lake area. The decline of the water table resulted in the increase of both the halite and sylvite contents and the electric conductivity values. 
a)
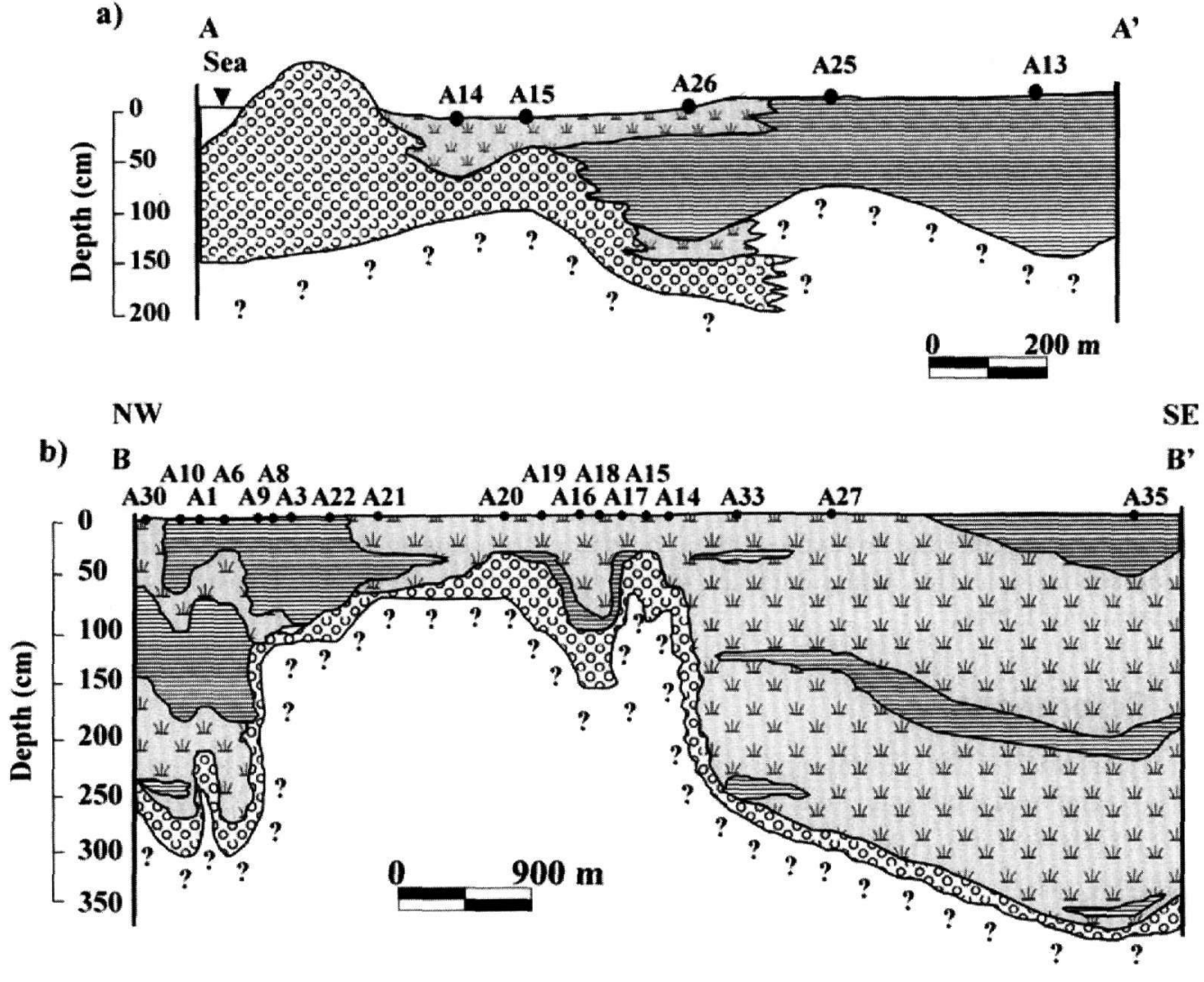

LEGEND

एस Organogenic sediment 당ㅇㅁ Sand Clay - Coring site

Figure 3 - SW-NE and NW-SE cross sections of the peatland. For the exact locations of both sections see Figure 1b

On the contrary, the high and relatively stable electric conductivity values and the higher contents of halite, sylvite and pyrite in samples from core $\mathrm{A}_{35}$ indicate that seawater influence was constant at the southeastern part of the mire throughout peat accumulation (Fig. 2b). Inorganic influx was also significant during peat accumulation with clastic silicate grains constituting the main inorganic fraction, whereas authigenic calcite is a minor mineral phase.

From the comparison of both profiles it is suggested that the central part of the peatland was mainly freshwater-dominated during peat accumulation, whereas seawater was entering the palaeomire from the southeastern margins, where the sand barrier displays its minimum width (Fig. 1b).

The overall data obtained from this study show that the Agoulinitsa peatland can be termed as back-barrier mire similar to those occurring along the eastern coast of Spain (López-Buendía et al. 1999). Similar conditions prevailed during Neogene times at several places in western Peloponnese, such as in Magoula, Koumouthekras and Kyparissia, resulting in significant lignite formations (Papazisimou 2002). Thus the Agoulinitsa peatland is considered as a modern analogue of these lignite deposits. 


\section{Concluding remarks}

The former Agoulinitsa Lake with the hosted peatland was a typical lagoonal environment formed behind sand dune barriers. Nevertheless, the results of the present preliminary study suggest that peat accumulated not strictly under brackish conditions, but a major part of the area was freshwater influenced mainly by the Alpheios River and its flooding events. The only part of the mire affected by seawater seems to be restricted at the south, where the sand dunes appear to be narrow. There maybe existed a seawater entrance into the mire.

In terms of peat geology, the Agoulinitsa peatland can be characterized as coastal back-barrier mire being one of the very few occurring in Greece. Further study concerning the physicalchemical properties and mineralogical composition of the peat is needed in order to reconstruct in detail the palaeoenvironmental conditions that led to the formation of the whole sedimentary sequence.

\section{Acknowledgements}

The authors would like to express their gratitude for assistance during the fieldwork to Dr. Antonis Bouzinos, Mrs. Tonia Paraschi, and Mr. Aris Liontos, from the Department of Geology, University of Patras.

\section{References}

American Society for Testing and Materials (ASTM), D3173, 1993. Moisture in the Analysis Sample of Coal and Coke. In 1996 Anmual book of ASTM Standards, Standards Relating to Gaseous fuels; Coal and Coke. 05.05, 289-290, Philadelphia, PA., ASTM, 495pp.

Andrejko, M.J., Fiene, F., and Cohen, A.D., 1983. Comparison of ashing techniques for determination of the inorganic content of peats. In P.M. Jarrett (ed.), ASTM Special Technical Publication 820, Testing of Peats and Organic Soils. 5-19, Philadelphia, PA., ASTM, 241pp.

Bouzinos, A., Broussoulis, J., and Christanis, K., 1994. Conservation and Management of Greek Fens: a "model" to avoid, Proceedings International Symposium "Conservation and Management of Fens", Warsaw-Biebrza, 6-10 June, 225-230.

Bouzinos, A., Christanis, K., and Kotis, T., 1997. The Chimaditida Fen (W. Macedonia, Greece): a peat deposit lost, International Peat Journal, 7, 3-10.

Bouzinos, A., Papazisimou, S., Christanis, K., and Tzedakis, P., 2001. High rate of peat accumulation in the tectonic depression of Katouna, western Greece, International Peat Journal, 10, 85-95.

Christanis, K., 1994. The genesis of the Nissi peatland (northwestern Greece) as an example of peat and lignite deposit formation in Greece, International Journal of Coal Geology, 26, 63-77.

Christanis, K., 1996. The peat resources in Greece. In E. Lappalainen (ed.), Global peat resources. 87-94, Finland, International Peat Society, 368pp.

Dellwig, O., Watermann, F., Brumsack, H.J., Gerdes, G., and Krumbein, W.E., 2001. Sulphur and iron geochemistry of Holocene coastal peats (NW Germany): a tool for palaeoenvironmental reconstruction, Palaeogeography, Palaeoclimatology, Palaeoecology, $167,359-379$.

Diessel, C.F.K., 1992. Coal-bearing Depositional Systems, Berlin, Springer Verlag, 721pp. 
Göttlich, K., 1990. Moor und Torfkunde, Stuttgart, E. Schweizerbart'sche Verlagsbuchhandlung, $529 \mathrm{pp}$.

Joosten, H., and Clarke, D., 2002. Wise use of mires and peatlands, Finland, International Mire Conservation Group and International Peat Society, 304pp.

Kalaitzidis, S., and Christanis, K., 2004. Mineral matter in Greek peat - a qualitative approach, Proc. of the $5^{\text {th }}$ International Symposium on Eastern Mediterranean Geology, Thessaloniki, Greece, 14-20 April, vol. 3, 1416-1419.

Kamberis, E., 1987. Geological and oil-geology study of NW Peloponnesus, Ph.D. Thesis, Athens Polytechnical School, Athens, Greece, 143pp.

Kearns, F., and Davison, A., 1983. Field classification system of organic-rich sediments, Proc. of Workshop Mineral matter in peat: its occurrence, form and distribution, Los Alamos, New Mexico, 26-39 September, 147-157.

Koukouvelas, I., Mpresiakas, A., Sokos, E., and Doutsos, T., 1996. The tectonic setting and earthquake ground hazards of the 1993 Pyrgos earthquake, Peloponnese, Greece, Journal of Geological Society of London, 153, 39-49.

Lappalainen, E. (ed.), 1996. Global peat resources, Finland, International Peat Society, 368pp.

López-Buendía, A.M., Bastida, J., Querol, X., and Whateley, M.K.G., 1999. Geochemical data as indicators of palaeosalinity in coastal organic-rich sediments, Chemical Geology, 157, 235-254.

Manariotis, I., and Yannopoulos, P., 2004. Adverse Effects on Alfeios River Basin and an Integrated Management Framework Based on Sustainability, Environmental Management, 34, 261-269.

Moore, E.S., and Bellamy, D.J., 1976. Peatlands, Berlin Heidelberg, New York, Springer, 221pp.

Natura 2000. http://natura.minenv.gr/natura/server/user/biotopos_info.asp?siteCode=GR2330001.

Papazisimou, S., 2002. Formation and evolution of coastal lignite seams in western Peloponnese. Ph.D. Thesis, Dept. of Geology, Univ. Patras, Patras, 226pp.

Papazisimou, S., Bouzinos, A., Christanis, K., and Tzedakis, P.C., 2000. The coastal asphalt fen of Keri, Zakynthos (Hellas), Proceedings of the $11^{\text {th }}$ International Peat Congress, vol. I, Quebec, Canada, August 6-12, 58-69.

Papazisimou, S., Bouzinos, A., Christanis, K., Tzedakis, P.C., and Kalaitzidis, S., 2002. The upland Holocene transitional mires of Elatia forest, Northern Greece, Wetlands, 22, 355-365.

Papazisimou, S., and Kalaitzidis, S., 2004. Quantitative mineral matter determination in lignites using X-Ray diffractometry and position sensitive detector (XRD-PSD), Proceedings of the $10^{\text {th }}$ International Congress of the Geological Society of Greece, vol. XXXVI, Thessaloniki, April, 464-473.

Papazisimou, S., Kalaitzidis, S., Christanis, K., Cressey, G., and Valsami-Jones, E., 2004. Accurate Phase Quantification of Mineral Matter in Bulk Lignite Samples from Western Peloponnese (Greece), Energy \& Fuels, 18, 547-559.

Psilovikos, A., 1992. Changes in Greek wetlands during the twentieth century: the cases of the Macedonian inland waters and of the river deltas of the Aegean and Ionian coasts, Proc. of Workshop on Greek Wetlands, Thessaloniki, Greece, 17-21 April 1989, 175-196.

Querol, X., Alastuey, A., Zhuang, X., Hower, J.C., Lopez-Soler, A., Plana, F., and Zeng, R., 2001. Petrology, mineralogy and geochemistry of the Permian and Triassic coals in the 
Leping area, Jiangxi Province, southeast China, International Journal of Coal Geology, 48, $23-45$.

Raymond, J.R., Andrejko, M.J., and Bardin, S.W., 1983. Techniques for applying scanning electron microscopy to the study of mineral matter in peat. In R.J. Raymond and M.J. Andrejko (eds), Mineral matter in peat. 169-179, Los Alamos, Los Alamos Laboratory, NM.

Schneekloth, H., 1981. Kartierung von Mooren. In F. Bender (ed.), Angewandte Geowissenschaften 1. 35-37, Stuttgart, Enke.

Shotyk, W., 1988. Review of the inorganic geochemistry of peats and peatland waters, EarthScience Reviews, 25, 95-176.

van der Molen, W., and Smits, H., 1962. Die Sackung in einem Moorgebiet in Nord-Griechenland (Philippi), Bremen, Unpubl. Report, 11 pp.

Ward, C.R., 2002. Analysis and significance of mineral matter in coal seams, International Journal of Coal Geology, 50, 135-168. 